\title{
Moderating Effect of Gender in Repatronage Behavioral Intention: The Role of Personal Characteristics
}

\author{
Yue-Teng Wong ${ }^{1}$, Syuhaily Osman ${ }^{2}$, Aini Said ${ }^{1} \&$ Laily Paim ${ }^{1}$ \\ ${ }^{1}$ Department of Resource Management and Consumer Studies, Faculty of Human Ecology, University Putra \\ Malaysia, Malaysia \\ ${ }^{2}$ Centre of Excellent for Sustainable Consumption Studies, Faculty of Human Ecology, Universiti Putra \\ Malaysia, Malaysia \\ Correspondence: Yue-Teng Wong, Department of Resource Management and Consumer Studies, Faculty of \\ Human Ecology, Universiti Putra Malaysia, 43400 Serdang, Selangor, Malaysia. Tel: 60-1-2332-0822. E-mail: \\ yueteng22@gmail.com
}

Received: July 17, 2013 Accepted: August 20, 2013 Online Published: December 31, 2013

doi:10.5539/ass.v10n1p106 URL: http://dx.doi.org/10.5539/ass.v10n1p106

\begin{abstract}
The agendas of consumer-centric marketing and remarkable revolution of gender in consumption have prolonged the reformation in marketing module as to entice the repatronage shoppers. The focuses of this study were to examine the repatronage behavioral intention from the personal characteristic perspective and to identify the gender-invariant of the causal relationships. Specifically, this study aimed to investigate the relationships between personal characteristics (need for activity, impulsiveness, shopping confidence, interpersonal influence susceptibility, utilitarian and hedonic shopping orientations) and repatronage behavioral intention as well as to assess the moderation effects of gender on the relationships. Reasoned Action Approach was employed as the theoretical basis of the study. The responses from 569 apparel adult shoppers were used for data analysis. Personal characteristics were found significantly associated with the repatronage behavioral intention. There was a moderation effect of gender ascertained in the identified relationships. The present study discerned some important implications for the marketing practitioners to gain insight into the characteristics of their targeted shoppers as to customize and position their product offerings accordingly.
\end{abstract}

Keywords: repatronage behavioral intention, personal characteristics, gender differences, moderation effect

\section{Introduction}

Since the last few decades, the study of shopping behaviors has been of major focus in both academic and practical fields. Shopping behavior literature has supported that the patronage and repatronage behavioral intention as the paradigms of many marketers (Hellier, Geursen, Carr \& Rickard, 2003; Machleit, Meyer \& Eroglu, 2005; Seiders, Voss, Grewal \& Godfrey, 2005). The effort of maintaining re-visit shoppers is important for a business to continue in existence considering that the cost of maintaining an existing customer is much lesser than the cost of enticing a new customer (Wakefield \& Blodgett, 1994). Repatronage behavioral intention refers to the psychological loyalty of the customer, which reveal in customer commitment to continue visiting the store (Bettencourt, 1977). The attachment proneness of an individual is important in establishing the relationship quality and intensified sensitivity to behavioral loyalty (De Wulf, Oderkerden-Schroder \& Lacobucci, 2002). The repatronage behavioral intention is probably influenced by the shopping excitement and the desire to stay in shopping environment (Wakefield \& Baker, 1998). The agenda of consumer-centric marketing has to be prioritized as shoppers are constantly recognized as one of the most rewarding marketing assets. Therefore, the personal characteristic approach has to be given more emphasis as the shoppers tend to convey their personalities, psychological needs and wants and shopping orientations that are consistent with their dispositional traits in purchasing decisions (Huber, Herman \& Morgan, 2001; Kim \& Jin, 2002). To develop the constructs of this study, Reasoned Action Approach, as the most recent integrative framework of the theory of behavioral prediction (Fishbein \& Ajzen, 2010) has been utilized as the theoretical benchmark of the study. Based on the discussions above, this study attempted to provide a new insight in the apparel market industry by assessing the importance of personal-centric elements in influencing repatronge behavioral intention.

In the field of apparel studies, many studies have focused on the shopping behavior of the female shoppers and 
these studies have recommended similar studies to be carried out on the male shoppers (Bellenger \& Korgaonkar, 1980; Du Preez, 2003; Muzinich, Pecotich \& Putrevu, 2003). It is noted that there has been scant research concentrated on males and gender differences in the area of consumer behavior (Chen-Yu \& Seock, 2002). Shopper typologies research in pertinent to different shopping styles for men and women has gained its popularity recently (Bakewell \& Vincent-Wayne, 2004; Dholakia \& Chiang, 2003; Otnes \& McGrath, 2001). In addition, the theory of behavioral prediction of Reasoned Action Approach (Fishbein \& Ajzen, 2010) has outlined the existence of specific effect of gender differences on the attitude and behavioral control in influencing intentions. In line with these studies, there is a need to conduct research to broaden the understanding of shopping behavior across gender.

The two objectives of the study were (1) to investigate the relationships between personal characteristics and repatronage behavioral intention among adult apparel shoppers and to examine the moderation effect of gender on the relationships. The variables of need to activity, impulsiveness, shopping confidence, susceptibility to influence, utilitarian orientation and hedonic orientation have been included in the construct of personal characteristics. The moderation effect of gender served as the cross validation in the causal relationships between personal characteristics and repatronage behavioral intention.

\section{Literature Review}

\subsection{Reasoned Action Approach}

Reasoned action approach is the most recent integrative framework of the theory of behavioral prediction (Fishbein \& Ajzen, 2010). The theory serves as the psychological foundation for predicting and explaining intentions and actions in terms of attitudinal, normative and control beliefs. This guides the understanding of the contributors of human social behavior by knowing the sources of these beliefs. Within the theoretical framework of Reasoned Action Approach, it is supposed that human action involves both reasonably and spontaneous decision making from the underlying cognitive foundation of beliefs. These beliefs might be generated from various sources, such as personal experiences or interaction with others.

\subsection{Repatronage Behavioral Intention}

Human behavior is seen as a mutual determinism, which involves the interaction of personal, situational and behavioral factors (Bandura, 1977). Very often, an individual's behavior is uniquely shaped by his/her personality characteristics. Repatronage behavioral intention has been regarded as an important determinant in forecasting shopping behavior. Hellier et al. (2003) mirrored the repurchase intention as the decision of an individual to purchase a particular product/service from the same company considering his/her present situation and possible circumstances. Butcher (2005) viewed repurchase intention as a measurable service outcome while Soderlund and Ohman (2005) regarded repurchase intention as intention-as-expectation. The repatronage behavioral intention approach emphasized in this study was in comply with Reasoned Action Approach in proposing that positive attitude resided in behavioral intention can commonly be found in attitudinal study.

\subsection{Personal Characteristics}

The basic predispositions, traits adaptations and own perceptions are the three major elements identified in the personal differences. The inherited nature, external influences and actual profile are theorized as the connecting systems that interact with personality traits through the dynamic process (Costa \& McCrae, 1995). The six personal characteristics examined in the study were including of need for activity, impulsiveness, shopping confidence, interpersonal influence susceptibility, utilitarian and hedonic shopping orientations.

\subsubsection{Need for Activity}

The motivational element is found resided in the dimension of need for activity (Buss, 1988). A number of studies have found the trait of need for activity as the predictor in the context of customer orientation in performance ratings (Brown, Mowen, Donavan \& Licata, 2002), health eating and exercise behaviors (Adams \& Mowen, 2005), job resourcefulness (Licata, Mowen, Harris \& Brown, 2003), bargaining proneness (Mowen \& Harris, 2003), volunterism (Mowen \& Sujan, 2005), aggressive and distracted driving (Bone \& Mowen, 2006) and tanning and cosmetic surgery propensity (Mowen, Longoria \& Sallee, 2009). However, no attempt was identified to acknowledge the effect of the trait of need for activity in the context of apparel shopping behavior. Therefore, this study aimed to further ascertain the generalizability of the trait of need for activity by examining its relationship with repatronage behavioral intention among adult apparel shoppers.

\subsubsection{Impulsiveness}

The responses of impulsive consumers might be influenced by the affective experiences especially in the context 
of buying behavior (Strack, Werth \& Deutsch, 2006). According to Jones, Reynolds, Weun and Beatty (2003), impulsiveness buying, which is potentially unreflective in nature, may affect an individual's store loyalty. Moreover, Cole and Clow (2011) has further emphasized that individuals who identified with higher level of impulsiveness were having higher tendency to perform unplanned purchases, and consecutively showing greater repatronage behavioral intention. Morrison, Gan, Dubelaar and Oppewal's (2011) research was found consistent to the earlier findings by showing that impulsiveness as being evoked by positive mood state, may in turn affect the willingness to return to the store. Therefore, based on the discussions above, positive relationship between impulsiveness and repatronage behavioral intention was proposed in the study.

\subsubsection{Shopping Confidence}

Sannapu and Singh (2012) have outlined that shopping confidence is important in determining mall loyalty. Further, Paridon, Carraher and Carraher (2006) and Reynolds and Darden (1972) have delineated the influences of self-confidence on word of mouth communication. Besides, Wakefield and Inman (2003) have further enhanced the knowledge by hypothesizing the influences of consumption related self-confidence together with the income effect on consumer purchasing behavior. Based on the discussions of the significance of shopping confidence on the shopping outcomes, it was proposed in this study the positive relationship between shopping confidence and repatronage behavioral intention.

\subsubsection{Interpersonal Influence Susceptibility}

Turley and Milliman (2000) have mentioned that there is a influence of customer's affective state on repatronage behavioral intention in the service environment. When the patronage of a store or the consumption of a service becomes more visible, this may result in the higher tendency for the referential others to influence decision (Arora \& Stoner, 1995; Day \& Stafford, 1997). In a group setting, the relationship ties with the others will affect the degree of engagement with someone in the word of mouth behavior (Lee, Cotte \& Noseworthy, 2010). Similarly, in Buunk and Gibbons's (2007) evaluation of consumer behavior with regard to fashion products, it was revealed that social interaction and the reliance on peers' opinions are as important as the individual's self perception. Based on the arguments above, it was proposed that interpersonal influence susceptibility to be positively related to the repatronage behavioral intention.

\subsubsection{Utilitarian and Hedonic Shopping Orientations}

Repatronage behavioral intention may be comparable to a choice situation, in which the consumers are confronting with cognition decisions that involve reasons to substantiate and endeavors to accomplish ( $\mathrm{O}^{\prime}$ Curry \& Strahilevitz, 2001). Numerous studies have revealed that shoppers who perceive higher quality from utilitarian aspect of shopping are more likely to show repatronage behavioral intention (Babin \& Babin, 2001; Jones, Reynolds \& Arnold, 2006; Stoel, Wickliffe \& Lee, 2004). Hedonic experiences, which known to be more pleasurable to anticipate, have seen more readily to be accessed and salient in the memory when predict future consumption experience (Shiv \& Huber, 2000). Previous studies have provided empirical support that hedonic shopping motivation to be related to repatronage behavioral intention (Chang, Burns \& Francis, 2004; Jayawardhena \& Wright, 2009; Jones et al., 2006). Based on the discussions above, positive relationships between the shopping orientations of utilitarian and hedonic and repatronage behavioral intention were proposed in the study.

\subsection{Gender Differences in Shopping Behavior}

Men and women were advocated to be treated as different entities in the consumer behavior studies because they are having distinctive values in shopping behaviors (Chang et al., 2004; Grewal, Baker, Levy \& Voss, 2003; Otnes \& McGrath 2001). The significant functioning of gender resided in consumer behavior study is undoubtedly deserving researchers' consideration (Costa, 2000; Palan, 2002; Stern, 1988). An individual's socialization occurrence may lead his/her affinity towards certain shopping roles (Evans, Christiansen \& Gill, 1996; Severiens \& Ten Dam, 1998). The gender role assumption has granted the differences in the adoption of socialization approach. This has lead to the notion that gender differences in the relationships between shopping orientation and repatronage behavior. However, the association is estimated to be weaker for male as compared to female as the higher involvement approach of female shoppers to be expected (Otnes \& McGrath, 2001). Women who treasured a lot on shopping would almost certainly value the intention of repatronage as a chance for them to spend more time and visit more often in shopping. However, men appeared to be less likely to extend their shopping experience even they have pleasure in it as they treat shopping as an expeditious process to solve problem.

Women shoppers have discovered more entertaining elements in shopping (Haytko \& Baker, 2004) and 
incorporated social interaction in the process of shopping experience (Otnes \& McGrath, 2001). Men shoppers were referred as wise shopper group given that they are incisive in shopping (Dennis, Newman \& Marsland, 2005). Other than that, impulsiveness purchases were probably more relevant for the products that reflect social image, self identity or normative evaluation. The trait was influenced by the social groups such as gender (Dittmar, Beattie \& Friese, 1995).

Female shoppers are more likely to view shopping activities as the expense of time and recreational activities (Noble, Griffith \& Adjei, 2006). On the other hand, male shoppers have perceived shopping as task orientated activity. Male and female shoppers have different shopping motivations whereby male shoppers are driven by information seeking and convenience attainment while female shoppers more apt to browsing behavior, variety seeking and social communication Moreover, male shoppers are found inclining to the individualistic goals by gathering information for making product or price comparisons. However, an inconsistent result has observed in the study of Hart, Farrell, Stachow, Reed and Cadogan (2007) proposing that hedonic value derived from shopping experience has a considerable favorable influence on shoppers' repatronage intentions especially among male shoppers. The inconsistencies in the arguments have created a space to investigate the intervention of gender in the relationships between personal characteristics and repatronage behavioral intention.

\subsection{Conceptual framework of the study}

The hypothesized model in this study was developed on the literature outlined in previous section. The conceptual model was stipulated by taking into account the six exogenous variables of need for activity, impulsiveness, shopping confidence, interpersonal influence susceptibility, utilitarian and hedonic shopping orientations and the endogenous variable of repatronage behavioral intention. The path diagram delineating the conceptual model is shown in Figure 1.

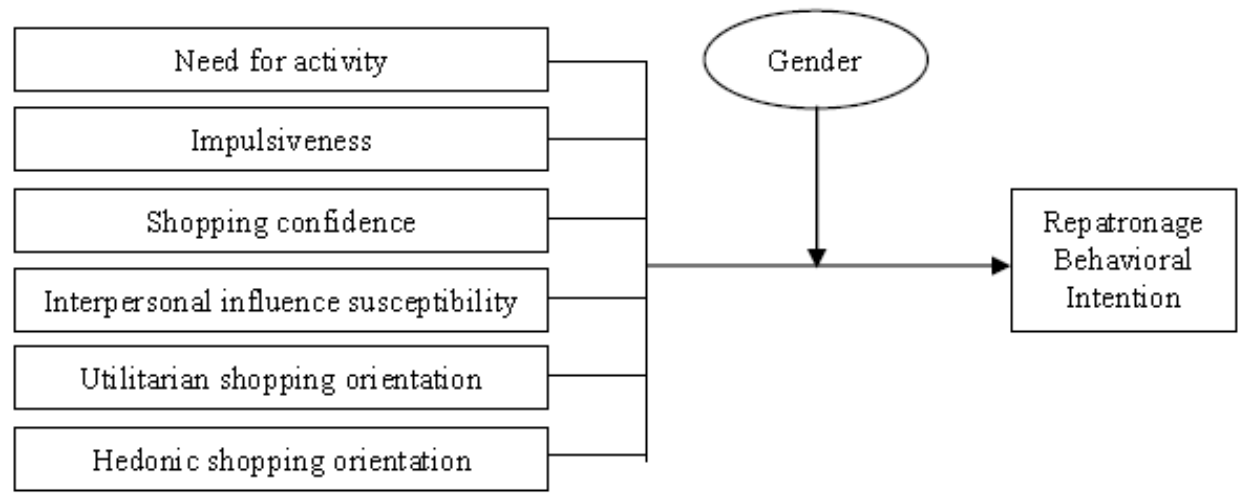

Figure 1. Conceptual model of the study

\section{Method}

\subsection{Sample and Procedure}

Using store-intercept technique, a total sample of 569 (285 males and 284 females) was drawn from the adult apparel shoppers. The data were gathered from the five regional shopping malls in Klang Valley, Malaysia, i.e., Mid Valley Megamall, 1Utama, Berjaya Times Square, Sunway Pyramid and The Mines. Both the oral and written permissions from the respective stores were granted before the data collection. A convenience quota sampling was applied to collect information from both males and females aged between 30 and 60 years old. Costa and McCrae (2002) has proposed that the stability and maturity of the personality traits maintain at the age of 30. In order to obtain optimal result for the study, the researchers have placed the age range as the selection criteria among the respondents. The mean age of the respondents was 38 years $(\mathrm{SD}=6.931)$. The majority of the respondents were having the profiles of married with children $(51.5 \%)$, white collar workers $(65.7 \%)$ and education attainments of university or professional backgrounds (46.7\%).

A survey methodology with self-administrated questionnaire was used to collect a large number of quantitative responses. The initial consents of the respondents were gained prior to the distributions of the questionnaires. In addition, the respondents were assured with the confidentiality and anonymity of the information given. The respondents who returned the completed questionnaires were rewarded with the purchase vouchers as a sense of gratitude from the researchers. Data collection for this study was accomplished within the two-month period (Jun 
\& July, 2012) in both weekends and weekdays.

\subsection{Measures}

The measurements of this study were mainly adapted and adopted from previous studies. Almost all the constructs were assessed based on the five-point scale, ranging from 'strongly disagree' (1) to 'strongly agree' (5). The dimension of repatronage behavioral intention was the only construct assessed based on a seven-point scale, ranging from 'strongly disagree' (1) to 'strongly agree' (7). The inclusion of both five-point scale and seven-point scale was aimed to avoid the boredom in respondents.

Buss (1998) perceived the differences in activity level as the primary trait of human and it has been perceived as the persistency in active doing things. This study has applied Buss's (1998) three-item scale to assess the need for activity. Eysenck and Eysenck (1977) defined impulsiveness as the inclination of a person to act venturesome, instinctively, not thoughtfully and promptly. The dimension of impulsiveness in this study was assessed based on the four items adapted from Eysenck Impulsive Scale (Eysenck \& Eysenck, 1977). The four-item version of the measure of impulsiveness, with high factor loadings on the scale was used in the current study. In this study, the dimension of shopping confidence developed by Shim and Drake (1988) was reflected as the level of confidence in a person when dealing with shopping for clothing or accessories and displaying for the presentable self. To identify a respondent's degree of agreement with the shopping confidence, this dimension was assessed based on the six items. Interpersonal influence susceptibility is interpreted as the tendency of an individual in obtaining information about products either by asking others' opinions or simply by observing the others (Bearden, Netemeyer \& Teel, 1989). This study has adopted the three-item abbreviation version of Boush, Friestad and Rose's (1994) instrument by extracting two items from the informational expression and another item from the normative expression in the original instrument of Bearden et al., 1989). Sproles and Kendall's (1986) scale of utilitarian and hedonic orientations was used in this study. The hedonic orientated shoppers are referring to those who demonstrate high propensity in seeking eminent brand and stylish items. Meanwhile, the utilitarian orientated people are referring to those who score high in the emphasis of quality and price properties. To identify a respondent's utilitarian and hedonic shopping orientations, these dimensions were assessed based on the twelve items, comprise of eight hedonic orientation items and four utilitarian orientation items. Repatronage behavioral intention is a subjective perception, which intends to measure the likelihood of a shopper to resolve the patronize decision in the future. To reflect the operational definition of repatronage behavioral intention in this study, the eleven-item measurement mainly from De Wulf, Oderkerden-Schroder and Lacobucci (2002)'s relationship commitment, Bettencourt (1997)'s commitment to store and Steenkamp and Baumgartner (1992) and Campo, Gijsbrechts and Nisol (2000)'s general store loyalty were adopted.

\section{Results}

\subsection{Correlations between Personal Characteristics and Repatronage Behavioral Intention}

Firstly, Pearson correlation analysis was used to examine the overall patterns of relationships among the variables as identified in objective 1 of the study. Information such as bivariate correlations, means and standard deviation are included in Table 1. As proposed by Kline (2010), the VIF values greater than 10 and the tolerances lesser than 0.10 are the indicators of multicollinearity. The diagnostic analysis conducted $(1.262 \leq \mathrm{VIF} \leq 1.483$; $0.674 \leq$ Tolerance $\leq 0.792$ ) has revealed that there was no multicollinearity concern in the study. The results demonstrated that all the personal characteristics have linear significant relationships with repatronage behavioral intention. Therefore, this study revealed that personal characteristics were significantly related to repatronage behavioral intention of adult apparel shoppers Due to the significant relationships observed between all the variables and repatronage behavioral intentions, the same variables were included in the structural model analysis. 
Table 1. Correlations between personal characteristics and repatronage behavioral intention

\begin{tabular}{lccccccc}
\hline \multicolumn{1}{c}{ Variable } & 1 & 2 & 3 & 4 & 5 & 6 & 7 \\
\hline 1. Repatronage behavioral intention & & & & & & & \\
2. Activity for activity & $0.436^{* * *}$ & & & & & & \\
3. Impulsiveness & $0.389^{* * *}$ & $0.397^{* * *}$ & & & & & \\
4. Shopping confidence & $0.412^{* * *}$ & $0.407^{* * *}$ & $0.347^{* * *}$ & & & & \\
5.Interpersonal influence susceptibility & $0.364^{* * *}$ & $0.330^{* * *}$ & $0.336^{* * *}$ & $0.282^{* * *}$ & & & \\
6. Utilitarian shopping orientation & $0.357^{* * *}$ & $0.295^{* * *}$ & $0.338^{* * *}$ & $0.275^{* * *}$ & $0.350^{* * *}$ & & \\
7. Hedonic shopping orientation & $0.582^{* * *}$ & $0.467^{* * *}$ & $0.395^{* * *}$ & $0.384^{* * *}$ & $0.336^{* * *}$ & $0.306^{* * *}$ & \\
$\quad$ Mean & 4.220 & 2.493 & 2.781 & 3.032 & 2.852 & 3.422 & 2.468 \\
$\quad$ Standard deviation & 1.394 & 0.831 & 0.910 & 0.933 & 0.927 & 0.942 & 0.866 \\
$\quad$ Construct reliability & 0.957 & 0.884 & 0.890 & 0.954 & 0.880 & 0.914 & 0.928 \\
\hline
\end{tabular}

Note: $* * * p<0.001$

\subsection{Gender Differences}

In order to identify whether the configuration of relationships proposed in the conceptual model follows the same dynamic for the male and female shoppers as proposed in the second objective of the study, multiple group analysis in SEM was performed. The hypothesized model was examined by the maximum likelihood estimation practice within the SEM framework. It is crucial to perform a multi-group analysis for the measurement model prior to conduct the multi-group analysis for the structural model. As a prerequisite to make comparisons at the structural model level, measurement invariance has to be established (Hair et al., 2010). Measurement invariance is important to ensure that cross validation is achieved with equivalent representation of the same construct under different conditions despite construct validity has been validated in the development stage. Steenkamp and Baumgartner (1998) have proposed that configural invariance as a sufficient requirement for identifying the construct comparability across different groups. This basic level of invariance sufficed the examination of basic structure of the construct in a cross-group manner as male and female respondents in this study were selected from the same region and believed to interpret the items in the same way. Configural invariance was established when (1) a robust model fit is achieved (2) the item loadings are significant and considerable (3) large modification indices are not present and (4) discriminant validity between the factors is attained. The baseline models are referring to those group-specific models with no between-groups constraints. The configural invariance in the hypothesized structural model for the male and female samples in this study has been achieved as a well-fitting baseline model was established for each group separately. After performing the modification indices to the revised model, the measurement models for the male and female samples were indicative of good fit with RMSEA $=0.058, \mathrm{NFI}=0.916, \mathrm{TLI}=0.937, \mathrm{CFI}=0.943$ and $\chi 2 / \mathrm{df}=2.900$. The GOF indices showed that NFI, TLI and CFI have significantly passed the threshold of 0.90 (Bentler, 1990). In addition, the RMSEA value of 0.058 (below 0.08) was found in satisfactory fit (MacCallum, Browne \& Sugawara, 1996). Furthermore, the chi-square/df value of 2.900 (below 3.0) also portrayed relatively good fit (Schumacker \& Lomax, 2010).

Table 2 outlines the chi-square goodness-of-fit statistics and baseline comparisons fit indices. The baseline comparisons fit indices of IFI, TLI and CFI for both models are above 0.90 even though the chi-square tests for the models recorded poor fit with statistically significant. The RMSEA values for group variant and group invariant path models are 0.044 and 0.046 respectively, suggestive of adequate fit. The Akaike's Information Criterion (AIC) which has the bearing on model parsimony and model fit was then used to compare the model fit for the two models. Simple and well-fitted model is indicated with low scores. The AIC value for the group variant model (2612.347) is lower than the group invariant model (2764.894), implying that the group variant model outweighs the other one with better fitting and more parsimonious in model. Based on the model comparison results and supposing that group variant model is appropriate, the group variant model's estimates are desirable over the group invariant model's estimates. 
Table 2. Summary of fit indices for male and female group invariant and group variant

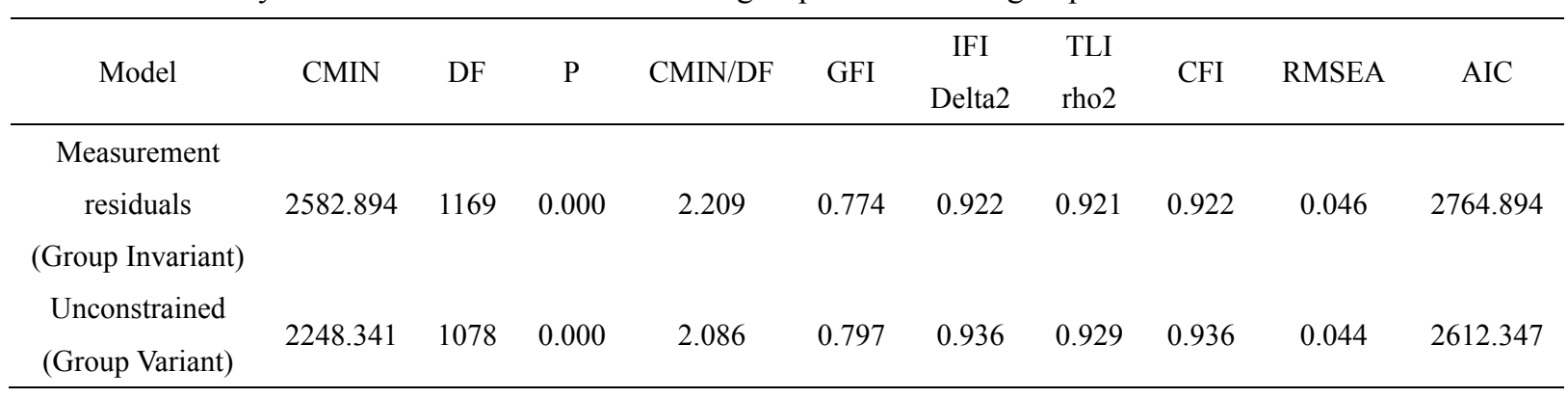

The direct comparison of the fit indices was conducted for the two opposing models. Table 3 indicates the model comparison assessments for the group variant and group invariant measurement models. As can be seen from the Nested Model Comparisons, the chi-square discrepancy value for the two models is 334.554 (2582.894 2248.341). Besides, with 91 degrees of freedom (1169 - 1078), the value is significant at the 0.05 level $(p=$ 0.0001). As a result, the two models are differing significantly in their goodness-of-fit. Hence, the gender moderated the causal relationships in the model because a more parsimonious and better fitting found in the group variant model between male and female shoppers. Hence, it is concluded that male and female shoppers in the hypothesized repatronage behavioral intention structural model do not share the same regression weights. The findings showed that gender moderated the relationships between personal characteristic and repatronage behavioral intention.

Table 3. Nested model comparisons for male and female group invariant and group variant

\begin{tabular}{ccccccccc}
\hline \multicolumn{2}{l}{ Assuming model } & \multicolumn{1}{l}{ group variant to be correct: } \\
\hline Model & DF & CMIN $\left(X^{2}\right)$ & P & NFI & IFI & RFI & TLI \\
Delta-1 & Delta-2 & rho-1 & rho2 \\
$\begin{array}{c}\text { Measurement residuals } \\
\text { (Group Invariant) }\end{array}$ & 91 & 334.554 & 0.000 & 0.017 & 0.018 & 0.008 & 0.008 \\
\hline
\end{tabular}

\section{Conclusions and Implications}

The results of this study have implications for the retailers in designing marketing strategies, aiming at personal characteristics and specific gender. The overall model proposed that factors such as need for activity, impulsiveness, shopping confidence, interpersonal influence susceptibility and utilitarian shopping orientation and hedonic shopping orientation affect the tendency of repatronage behavioral intention. In line with that, the result of this study supports the earlier work of Cole and Clow (2011) and Gan et al. (2011) on the influence of impulsiveness on repatronage behavioral intention. In addition, this study corroborates the previous findings (Paridon et al., 2006; Sannapu \& Singh, 2012; Wakefield \& Inman, 2003) about the importance of shopping confidence in determining repatronage behavioral intention. The correlation found in interpersonal influence susceptibility and repatronage behavioral intention is similar to those described by Arora and Stoner (1995) and Turley and Milliman (2000). The present findings seem to be consistent with a great deal of previous research which found the relationship between utilitarian shopping orientation and repatronage behavioral intention (Babin \& Babin, 2001; Jones et al., 2006; Stoel et al., 2004). The findings in this study further support the idea of linear relationship between hedonic shopping orientation and repatronage behavioral intention as proposed by Chang et al. (2004), Jayawardhena and Wright (2009) and Jones et al. (2006).

The moderation analysis showed that the moderation effect of gender on the relationship between personal characteristics and repatronage behavioral intention. The results suggest that there are some discrepancies between the shopping behavior of males and females. The results are in tandem with the research of Chang et al (2005), Grewal et al (2003) and Otnes and McGrath (2001), revealing that the distinctive values of shopping behavior among the male and female shoppers. Owing to the incongruity of shopping behavior perceived by the adult apparel shoppers, the impacts of males and females have on the repatronage behavioral intention might be differed. The growing evidence of female working groups and the popularity of apparel shopping amongst male shoppers nowadays have given a light to redefine the meaning of 'shopping' to both genders. 
Limitations of the present study might provide directions for future studies. First, this study focused only on the overall moderation effect of gender on the hypothesized model. This study may be strengthened by furthering the understanding of the moderation effect in the individual path of the hypothesized model. Second, despite the parsimonious properties have been recognized in the causal relationship using path analysis, it disjoints the explorations of factors that might contribute to the study variables. It is possible that other methods might identify the potential variables to the study variables.

The examination of the dynamic interaction between personal characteristics of both gender and repatronage behavioral intention is beneficial in marketing strategy formulation. It is imperative for the retailers to establish integrated shopper-company relationship to gain insight into the characteristics of their targeted shoppers. This enables the retailers to be informed about the personal needs and desires of the shoppers by understanding their opinions, values and motivations. The strategy of considering personal characteristics of shoppers in product design and positioning might provide the basis for product differentiation and greater value creation of the company. The ultimate aim of these efforts could have led to satisfied shoppers who display repatronage behavioral intention. This may result in long-term profitability with the implementation of consumer-centric marketing. The notion of this study is consistent with Reasoned Action Approach, which advocates that behaviors are predicted by the psychological basis in terms of attitude, normative and control beliefs. Notwithstanding the limitations proposed earlier, this study provides empirical ground on the importance of personal characteristics in understanding repatronage behavioral intention among adult apparel shoppers.

\section{References}

Adams, T. B., \& Mowen, J. C. (2005). Identifying the personality characteristics of healthy eaters and exercisers: A hierarchical model approach. Health Marketing Quarterly, 23(1), 21-42. http://dx.doi.org/10.1300/J026v23n01_03

Arora, R., \& Stoner, C. (1995). Reference group influence on selection of services. Journal of Customer Service in Marketing and Management, l(3), 79-93. http://dx.doi.org/10.1300/J127v01n03_07

Babin, B. J., \& Babin, L. (2001). Seeking something different? A model of schema typicality, consumer affect, purchase intentions and perceived shopping value. Journal of Business Research, 54(2), 89-96. http://dx.doi.org/10.1016/S0148-2963(99)00095-8

Bakewell, C., \& Vincent-Wayne, M. (2004). Male consumer decision making styles. International Review of Retail Distribution and Consumer Research, 14 (2), 223-240. http://dx.doi.org/10.1080/0959396042000178205

Bandura, A. (1997). Self-efficacy: The Exercise of Control. New York: Freeman.

Bearden, W. O., Netemeyer, R., \& Teel, J. E. (1989). Measurement of consumer susceptibility to interpersonal influence. Journal of Consumer Research, 15(4), 473-481. http://www.jstor.org/stable/2489543

Bellenger, D. N., \& Korgaonkar, P. (1980). Profiling the recreational shopper. Journal of Retailing, 56(3), 77-92.

Bentler, P. M. (1990). Comparative fit indexes in structural models. Psychological Bulletin, 107(2), 238-246. http://escholarship.org/uc/item/6cn677bx

Bettencourt, L. A. (1997). Customer voluntary performance: Customers as partners in service delivery. Journal of Retailing, 73(3), 383-406. http://dx.doi.org/10.1016/S0022-4359(97)90024-5

Bone, S., \& Mowen, J. C. (2006). Identifying the traits of aggressive and distracted driving: A hierarchical model approach, Journal of Consumer Behavior, 5, 454-464. http://dx.doi.org/10.1002/cb.193

Boush, D. M., Friestad, M., \& Rose, G. M. (1994). Adolescent skepticism toward TV advertising and knowledge of advertiser tactics. Journal of Consumer Research, 2l(1), 165-175. http://www.jstor.org/stable/2489748

Brown, T. J., Mowen, J. C., Donavan, D. T., \& Licata, J. W. (2002). The customer orientation of service workers: personality trait effects on self-and supervisor performance ratings. Journal of Marketing Research, 39(1), 110-119. http://dx.doi.org/10.1509/jmkr.39.1.110.18928

Buss, A. H. (1988). Personality: Evolutionary Heritage and Human Distinctiveness. Hillsdale. N.J.: Lawrence Erlbaum Associates.

Butcher, K. (2005). Differential impact of social influence in the hospitality encounter. International Journal of Contemporary Hospitality Management, 17(2), 125-135. http://dx.doi.org/10.1108/09596110510582323

Buunk, A. P., \& Gibbons, F. X. (2007). Social comparison: The end of a theory and the emergence of a field. Organizational Behavior and Human Decision Process, 102(7), 3-21. http://dx.doi.org/10.1016/j.obhdp.2006.09.007 
Campo, K., Gijsbrechts, E., \& Nisol, P. (2000). Towards a theory-based measure of purchase variation. Academy of Marketing Science Review, 6. http://www.amsreview.org/articles/gijsbrechts06-2000.pdf

Chang, E., Burns, L. D., \& Francis, S. K. (2004). Gender differences in the dimensional structure of apparel shopping satisfaction among Korean consumers: The role of hedonic shopping value. Clothing and Textiles Research Journal, 22(4), 185-199. http://dx.doi.org/10.1177/0887302X0402200404

Chen-Yu, J. H., \& Seock, Y. K. (2002). Adolescents' clothing purchase motivations, information sources, and store selection criteria: A comparison of male/female and impulse/non-impulse shoppers. Family and Consumer Sciences Research Journal, 31(1), 51-77. http://dx.doi.org/10.1177/1077727X02031001003

Cole, H. S., \& Clow, K. E. (2011). A model development of retail patronage loyalty. Journal of Business Studies Quarterly, 2(2), 1-16. Retrieved from http://jbsq.org/wp-content/uploads/2011/03/March-2011-1D.pdf

Costa, J. A. (2000). Gender and consumption in a cultural context. In M. Catterall, P. Maclaran, \& L. Stevens (Eds.), Marketing and feminism: Current issues and research (pp. 255-275). Routledge.

Costa Jr, P. T., \& McCrae, R. R. (1995). Solid ground in the wetlands of personality: A reply to Block. Psychological Bulletin, 117(2), 216-220. http://dx.doi.org/10.1037/0033-2909.117.2.216

Costa Jr, P. T., \& McCrae, R. R. (2002). Looking backward: Changes in the mean levels of personality traits from 80 to 12. In D. Cervone, \& W. Mischel (Eds.), Advances in Personality Science. New York: Guilford Press.

Day, E., \& Stafford, M. R. (1997). Age-related cues in retail services advertising: Their effects on younger consumers. Journal of Retailing, 73(2), 211-233. http://dx.doi.org/10.1016/S0022-4359(97)90004-X

De Wulf, K., Odekerken-Schroder, G., \& Lacobucci, D. (2002). Investments in consumer relationships: A cross-country and cross industry exploration. Journal of Marketing, 65(4), 18-51. http://dx.doi.org/10.1509/jmkg.65.4.33.18386

Dennis, C., Newman, A., \& Marsland, D. (2005). Objects of Desire: Consumer Behaviour in Shopping Centre Choices. Palgrave Macmillan, Basingstoke .

Dholakia, R. R., \& Chiang, K. P. (2003). Shoppers in cyberspace: Are they from Venus or Mars and does it $\begin{array}{lllll}\text { matter? Journal of } & \text { Consumer }\end{array}$ http://dx.doi.org/10.1207/S15327663JCP13-1\&2_15

Dittmar, H., Beattie, J., \& Friese, S. (1995). Gender identity and material symbols: Objects and decision considerations in impulse purchases. Journal of Economic Psychology, 16(3), 491-511. http://dx.doi.org/10.1016/0167-4870(95)00023-H

Du Preez, R. (2003). Apparel shopping behavior - part 1: Towards the development of a conceptual theoretical model. SA Journal of Industrial Psychology, 29(3), 11-14. http://hdl.handle.net/10019.1/21169

Evans, K. R., Christiansen, T., \& Gill, J. D. (1996). The impact of social influence and role expectations on shopping center patronage intentions. Journal of the Academy of Marketing Science, 24(3), 208-218. http://dx.doi.org/10.1177/0092070396243002

Eysenck, S. B. G., \& Eysenck, H. J. (1977). The place of impulsiveness in a dimensional system of personality description. British Journal of Social and Clinical Psychology, 16(1), 57-68. http://dx.doi.org/10.1111/j.2044-8260.1977.tb01003.x

Fishbein, M., \& Ajzen, I. (2010). Predicting and Changing Behavior: The Reasoned Action Approach. New York, NY: Psycology Press. Taylor \& Francis Group.

Grewal, D., Baker, J., Levy, M., \& Voss, G. B. (2003). The effects of wait expectations and store atmosphere evaluations on patronage intentions in service-intensive retail stores. Journal of Retailing, 79(4), 259-268. http://dx.doi.org/10.1016/j.jretai.2003.09.006

Hair, J. F., Black, W. C., Babin, B. J., \& Anderson, R. E. (2010). Multivariate Data Analysis (7th ed.). Upper Saddle River: Pearson.

Hart, C., Farrell, A. M., Stachow, G., Reed, G., \& Cadogan, J. W. (2007). Enjoyment of the shopping experience: Impact on customers' repatronage intentions and gender influence. The Service Industries Journal, 27(5), 583-604. http://dx.doi.org/10.1080/02642060701411757

Haytko, D. L., \& Baker, J. (2004). It's all at the mall: Exploring adolescent girls' experiences. Journal of Retailing, 80(1), 67-83. http://dx.doi.org/10.1016/j.jretai.2004.01.005

Hellier, P. K., Geursen, G. M., Carr, R. A., \& Rickard, J. A. (2003). Customer repurchase intention: A general structural equation model. European Journal of Marketing, 37(11-12), 1762-1800. 
http://dx.doi.org/10.1108/03090560310495456

Jayawardhena, C., \& Wright, L. T. (2009). An empirical investigation into e-shopping excitement: Antecedents and effects. European Journal of Marketing, 43(9-10), 1171-1187. http://dx.doi.org/10.1108/03090560910976429

Jones, M. A., Reynolds, K. E., Weun, S., \& Beatty, S. E. (2003). The product specific nature of impulse buying tendency. Journal of Business Research, 56(7), 505-511. http://dx.doi.org/10.1016/S0148-2963(01)00250-8

Jones, M. A., Reynolds, K. E., \& Arnold, M. (2006). Hedonic and utilitarian shopping value: Investigating differential effects on retail outcomes. Journal of Business Research, 59(9), 974-981. http://dx.doi.org/10.1016/j.jbusres.2006.03.006

Kim, O. K., \& Jin, B. (2002). Korean consumers' patronage of discount stores: Domestic vs. multinational discount store shoppers' profiles. The Journal of Consumer Marketing, 18(3), 236-255. http://dx.doi.org/10.1108/07363760110393092

Kline, R. B. (2010). Principles and Practice of Structural Equation Modeling (3rd ed.). New York: Guilford Press.

Lee, S. H., Cotte, J., \& Noseworthy, T. J. (2010). The role of network centrality in the flow of consumer influence. Journal of Consumer Psychology, 20(1), 66-77. http://dx.doi.org/10.1016/j.jcps.2009.10.001

Licata, J. W., Mowen, J. C., Harris, E. G., \& Brown, T. J. (2003). On the trait antecedents and outcomes of service worker job resourcefulness: A hierarchical model approach. Journal of the Academy of Marketing Science, 31(3), 256-271. http://dx.doi.org/10.1177/0092070303252599

MacCallum, R. C., Browne, M. W., \& Sugawara, H. M. (1996). Power analysis and determination of sample size for covariance structure modeling. Psychological Methods, 1(2), 130-149. http://dx.doi.org/10.1037/1082-989X.1.2.130

Machleit, K., Meyer, T., \& Eroglu, S. (2005) Evaluating the nature of hassles and uplifts in the retail shopping context. Journal of Business Research, 58(5), 655-663. http://dx.doi.org/10.1016/j.jbusres.2003.09.006

Mburu, P. T., Mutua, K., \& Massimo, S. K. (2002). A study of apparel buyer motivations. Journal of Applied Science, 2(6), 673-681. http://dx.doi.org/10.3923/jas.2002.673.681

Morrison, M., Gan, S., Dubelaar, C., \& Oppewal, H. (2011). In-store music and aroma influences on shopper behavior and satisfaction. Journal of Business Research, 64(4), 558-564. http://dx.doi.org/10.1016/j.jbusres.2010.06.006

Mowen, J. C., \& Harris, E. G. (2003). The MDPS method of message theme development: A new tool for managers. Journal of Consumer Marketing, 20(5), 428-445. http://dx.doi.org/10.1108/07363760310489661

Mowen, J. C., \& Sujan, H. (2005). Volunteer behavior: A hierarchical model approach for investigating its trait and functional motive antecedents. Journal of Consumer Psychology, 15(2), 170-182. http://dx.doi.org/10.1207/s15327663jcp1502_9

Mowen, J. C., Longoria, A., \& Sallee, A. (2009). Burning and cutting: Identifying the traits of individuals with an enduring propensity to tan and to undergo cosmetic surgery. Journal of Consumer Behavior, 8(5), 238-251. http://dx.doi.org/10.1002/cb.284

Muzinich, N., Pecotich, A., \& Putrevu, S. (2003). A model of the antecedents and consequents of female fashion innovativeness. Journal of Retailing and Consumer Services, 10(5), 297-310. http://dx.doi.org/10.1016/S0969-6989(02)00060-7

Noble, S. M., Griffith, D. A., \& Adjei, M. T. (2006). Drivers of local merchant loyalty: Understanding the influence of gender and shopping motives. Journal of Retailing, 82(3), 177-188. http://dx.doi.org/10.1016/j.jretai.2006.05.002

O'Curry, S., \& Strahilevitz, M. (2001). Probability and mode of acquisition effects on choices between hedonic and utilitarian options. Marketing Letters, 12(1), 37-49. http://dx.doi.org/10.1023/A:1008115902904

Otnes, C., \& McGrath, M. A. (2001). Perceptions and realities of male shopping behavior. Journal of Retailing, 77(1), 111-137. http://dx.doi.org/10.1016/S0022-4359(00)00047-6

Palan, K. M. (2002). Gender identity in consumer behavior research: A literature review and research agenda. Academy of Marketing Science Review, 10, 1-26. http://www.amsreview.org/articles/palan10-2001.pdf

Paridon, T. J., Carraher, S., \& Carraher, S. C. (2006). The income effect in personal shopping value, consumer self-confidence, and information sharing (word of mouth communication) research. Academy of Marketing $\begin{array}{lllll}\text { Studies } & \text { Journal, } & \text { 10(2), } & \text { 107-124. } & \text { Retrieved }\end{array}$ 
http://www.alliedacademies.org/Publications/Papers/AMSJ\%20Vol\%2010\%20No\%202\%202006\%20p\%20 107-124.pdf

Reynolds, F. D., \& Darden, W. R. (1972). Intermarket patronage: A psychographic study of consumer outshoppers. Journal of Marketing, 36(4), 50-54. http://www.jstor.org/stable/1250427

Sannapu, S., \& Singh, N. (2012). Structural model for mall positioning. International Journal of Management and Strategy, 3(4), 1-30. $\quad$ Retrieved from http://www.facultyjournal.com/webmaster/upload/_jbs\%20paper.pdf

Schumacker, R., \& Lomax, R. (2010). A Beginner's Guide to Structural Equation Modeling (3rd ed.). Mahwah, N.J.: Lawrence Erlbaum Associates.

Seiders, K., Voss, G. B., Grewal, D., \& Godfrey, A. L. (2005). Do satisfied customers really buy more? Examining moderating influences in a retailing context. Journal of Marketing, 69(2), 26-43. http://dx.doi.org/10.1509/jmkg.69.2.84.60760

Severiens, S., \& Ten Dam, G. (1998). A multilevel meta-analysis of gender differences in learning orientations. $\begin{array}{llll}\text { British Journal of Educational Psychology, 68(4), } & \text { 595-608. }\end{array}$ http://dx.doi.org/10.1111/j.2044-8279.1998.tb01315.x

Shim, S., \& Drake, M. F. (1988). Apparel selection by employed women: A typology of information search patterns. Clothing and Textiles Research Journal, 6(2), 1-9. http://dx.doi.org/10.1177/0887302X8800600201

Shiv, B., \& Huber, J. (2000). The impact of anticipating satisfaction on consumer choice. Journal of Consumer Research, 27(2), 202-216. http://dx.doi.org/RePEc:ucp:jconrs:v:27:y:2000:i:2:p:202-16

Soderlund, M., \& Ohman, N. (2005). Assessing behavior before it becomes behavior: An examination of the role of intentions as a link between satisfaction and repatronizing behavior. International Journal of Service Industry Management, 16(2), 169-185. http://dx.doi.org/10.1108/09564230510592298

Sproles, G. B., \& Kendall, E. L. (1986). A methodology for profiling consumers' decision-making styles. Journal of Consumer Affairs, 20(2), 267-279. http://dx.doi.org/10.1111/j.1745-6606.1986.tb00382.x

Steenkamp, J. B., \& Baumgartner, H. (1992). The role of optimum stimulation level in exploratory consumer behavior. Journal of Consumer Research, 19(12), 434-448. http://www.jstor.org/stable/2489400

Steenkamp, J. B., \& Baumgartner, H. (1998). Assessing measurement invariance in cross-national research. Journal of Consumer Research, 25(1), 78-90. Retrieved from http://www.jstor.org/stable/10.1086/209528

Stern, B. (1988). Media use and gender differences: Retail strategies for bank marketers. The International Journal of Bank Marketing, 6(2), 20-31. http://dx.doi.org/10.1108/eb010828

Stoel, L., Wickliffe, V., \& Lee, K. H. (2004). Attribute beliefs and spending as antecedents to shopping value. Journal of Business Research, 57(12), 1067-1073. http://dx.doi.org/10.1016/S0148-2963(03)00016-X

Strack, F., Werth, L., \& Deutsch, R. (2006). Reflective and impulsive determinants of consumer behavior. Journal of Consumer Psychology, 16(3), 205-216. http://dx.doi.org/10.1207/s15327663jcp1603_2

Turley, L. W., \& Milliman, R. E. (2000). Atmospheric effects on shopping behavior: A review of the experimental evidence. Journal of Business Research, 49(2), 193-211. http://dx.doi.org/10.1016/S0148-2963(99)00010-7

Wakefield, K. L., \& Baker, J. (1998). Excitement at the mall: Determinants and effects on shopping response. Journal of Retailing, 74(4), 515-539. http://dx.doi.org/10.1016/S0022-4359(99)80106-7

Wakefield, K. L., \& Inman, J. J. (2003). Situational price sensitivity: The role of consumption occasion, social context, and income. Journal of Retailing, 79(4), 199-212. http://dx.doi.org/10.1016/j.jretai.2003.09.004

Wakefield, K. L., \& Blodgett, J. G. (1994). The importance of servicescape in leisure service settings. Journal of Services Marketing, 8(3), 66-76. http://dx.doi.org/10.1108/08876049410065624

\section{Copyrights}

Copyright for this article is retained by the author(s), with first publication rights granted to the journal.

This is an open-access article distributed under the terms and conditions of the Creative Commons Attribution license (http://creativecommons.org/licenses/by/3.0/). 